\title{
Removal of 3-methylindole by lactic acid bacteria in vitro
}

\author{
XIAO MENG ${ }^{1 *}$, ZHI-FEI HE ${ }^{1 *}$, HONG-JUN LI ${ }^{1}$ and XIN ZHAO ${ }^{2,3}$ \\ ${ }^{1}$ College of Food Science, Southwest University, Chongqing 400715; ${ }^{2}$ Department of Biological and Chemical Engineering, \\ Chongqing University of Education, Chongqing 400067, P.R. China; ${ }^{3}$ Department of Food \\ Science and Nutrition, Pusan National University, Busan 609-735, Republic of Korea
}

Received April 9, 2013; Accepted July 30, 2013

DOI: $10.3892 /$ etm.2013.1251

\begin{abstract}
Methylindole (3MI) is a substance with an unpleasant odor that is found in intact male pigs and is known to negatively affect consumers of pork. The growth of four strains of lactic acid bacteria [Lactobacillus brevis 1.12 (L. brevis 1.12), L. plantarum 102, L. casei 6103 and L. plantarum ATCC8014] in incubation medium with $3 \mathrm{MI}$ was studied. The four strains were tested for their ability to remove $3 \mathrm{MI}$ from the medium. The growth of L. brevis 1.12 remained steady as the levels of $3 \mathrm{MI}$ increased 3MI from 0.2 to $1.0 \mu \mathrm{g} / \mathrm{ml}$. The $3 \mathrm{MI}$ removal ability of L. brevis 1.12 was the strongest among the four strains, and the highest removal rate was $65.35 \pm 0.3 \%$ in $1 \mathrm{ml}$ incubation medium containing $1.0 \mu \mathrm{g} / \mathrm{ml} 3 \mathrm{MI}$ for $120 \mathrm{~h}$. Furthermore, the supernatant fluid of the fermentation broth of L. brevis 1.12 had a stronger ability to remove $3 \mathrm{MI}$ than cell pellets and cell extracts and the removal rate was $14.4 \pm 0.3 \%$ in $24 \mathrm{~h}$. Further results indicate that the mode of removal of 3MI was not through the physical binding of cells by L. brevis 1.12 .
\end{abstract}

\section{Introduction}

3-Methylindole (3MI) is a substance with an unpleasant odor (1-4) that is produced by the tryptophan removal process in the caecum and colon of intact male pigs $(5,6)$. It has been reported that consumers are able to detect the negative odor when the level of $3 \mathrm{MI}$ is $>0.21 \mathrm{mg} / \mathrm{kg}$ (7).

In numerous countries, the castration of male piglets is common practice to remove the odor. However, intact male pigs have demonstrated a superior performance compared with barrows, due to better carcass traits, lean meat percentage and

Correspondence to: Professor Hong-Jun Li, College of Food Science, Southwest University, 2 Tiansheng Road, Beibei, Chongqing 400715, P.R. China

E-mail: hongjunli1961@yahoo.com.cn

Dr Xin Zhao, Department of Biological and Chemical Engineering, Chongqing University of Education, 9 Xuefu Main Street, Nan'an, Chongqing 400067, P.R. China

E-mail: foods@live.cn

${ }^{*}$ Contributed equally

Key words: removal, 3-methylindole, lactic acid bacteria feed efficiency. Furthermore, the surgical castration of male piglets not only diminishes the benefits of intact male pigs, but also increases concerns about animal welfare (1). Surgical castration is not performed in Australia, the United Kingdom and Ireland. In Norway, a total ban on castration was initiated in January 2009 (8). However, if intact male pigs are to be used for pork production, the $3 \mathrm{MI}$ level must be substantially reduced. At present, a number of microbial methods have been used to investigate the problem in vitro. Compared with physical and chemical methods, biological techniques are preferable due to the economical advantages and low possibility of byproduct generation. Various bacterial strains have been applied to reduce the levels of harmful substances for a number of years. Ochrobactrum intermedium DN2 has been used to degrade nicotine in tobacco waste extracts and the average degradation rate of nicotine in a 301 fed-batch culture was $140.5 \mathrm{mg} / \mathrm{l} / \mathrm{h}(9)$. In addition, Shinella zoogloeoides BC026 has been identified to reduce pyridine levels, resulting in a degradation rate of $1,806 \mathrm{mg} / \mathrm{l}$ pyridine in $45.5 \mathrm{~h}$ (10). Moreover, Bacillus odysseyi SUK3, Morganella morganii SUK5 and Proteus species SUK7 have been shown to decolorize Reactive Blue $59(50 \mathrm{mg} / \mathrm{l})$ completely within 60, 30 and $24 \mathrm{~h}$, respectively (11). With regard to $3 \mathrm{MI}$ degradation, Kohda et al (12) identified that $0.05 \%(\mathrm{w} / \mathrm{v})$ 3MI may be degraded by a type of Clostridium from the feces of pigs in under 4 weeks with a removal rate of up to $32.18 \%$. Yin et al (13) demonstrated that $2.5 \mathrm{mmol} / 13 \mathrm{MI}$ may be reduced by Pseudomonas aeruginosa (extracted from the sediment of lapacho wood) in 3 days and the time was extended as the 3MI concentration increased from 2.5 to $3.5 \mathrm{mmol} / 1$. Additionally, $\mathrm{Gu}$ and Berry (14) indicated that $1-1.5 \mu \mathrm{mol} / 13 \mathrm{MI}$ was reduced in 36 days by a bacterial colony that produced methane. Furthermore, Gu et al (15) reported that 3MI may be completely degraded by sulfate-reducing bacteria.

The objectives of the present study were to investigate the growth of lactic acid bacteria [Lactobacillus brevis 1.12 (L. brevis 1.12), L. plantarum 102, L. casei 6103 and L. plantarum ATCC8014] in culture medium with varied concentrations of $3 \mathrm{MI}$, and to explore the correlation between the levels of $3 \mathrm{MI}$ and the $3 \mathrm{MI}$ removal ability of the lactic acid bacteria during the fermentation process in vitro.

\section{Materials and methods}

Strains and medium. L. brevis 1.12, L. casei 6103 and L. plantarum ATCC8014 were purchased from China 
Center of Industrial Culture Collection (Beijing, China). L. plantarum 102 was obtained from American Type Culture Collection (Manassas, VA, USA). MRS broth (Oxoid Ltd., Basingstoke, UK) was used as the culture medium for the lactic acid bacteria.

Chemicals and reagents. 3MI, acetonitrile and methanol of high-performance liquid chromatography (HPLC) grade were purchased from Sigma-Aldrich (St. Louis, MO, USA). Phosphate-buffered saline (PBS; Sigma-Aldrich) was of analytical grade. All remaining chemicals were of biological and analytical reagent grades, and were obtained from Kelong Chemical Reagent Factory (Chengdu, China).

Effects of 3MI on the growth of lactic acid bacteria. The 3MI standard solutions contained 0.0, 0.2, 0.4, 0.6, 0.8 and $1.0 \mathrm{~g} 3 \mathrm{MI}$ standard substance dissolved in $10 \mathrm{ml}$ absolute ethyl alcohol (w/v; 0.00, 0.02, 0.04, 0.06, 0.08 and $0.10 \mathrm{~g} / \mathrm{ml}$, respectively). The bacterial colonies of L. brevis 1.12, L. plantarum 102, L. casei 6103 and L.plantarum ATCC8014 were suspended in $10 \mathrm{ml} 0.75 \%(\mathrm{w} / \mathrm{v})$ physiological saline. Subsequently, 2.5\% $(\mathrm{v} / \mathrm{v})$ suspension liquid and $1 \mathrm{ml} 3 \mathrm{MI}$ solution were mixed with $100 \mathrm{ml}$ MRS medium for $72 \mathrm{~h}$ at $37^{\circ} \mathrm{C}$. The optical density (OD) value at $600 \mathrm{~nm}$ was detected every $2 \mathrm{~h}$ by a spectrophotometer (722-spectrophotometer; Tairui Instrument Co., Ltd., Chongqing, China) $(16,17)$.

Removal of 3 MI from the MRS broth by fermentation of lactic acid bacteria strains. $3 \mathrm{MI}$ standard substance $(0.0,0.2,0.4,0.6$, 0.8 and $1.0 \mathrm{~g}$ ) was dissolved in $10 \mathrm{ml}$ absolute ethyl alcohol to provide $3 \mathrm{MI}$ standard solutions $(0.00,0.02,0.04,0.06,0.08$ and $0.10 \mathrm{~g} / \mathrm{ml}$, respectively). Bacterial colonies of L. brevis 1.12, L. plantarum 102, L. casei 6103 and L. plantarum ATCC 8014 were suspended in $10 \mathrm{ml} 0.75 \%(\mathrm{w} / \mathrm{v})$ physiological saline. 3MI solution ( $1 \mathrm{ml})$ and $2.5 \%(\mathrm{v} / \mathrm{v})$ suspension liquid were mixed in $100 \mathrm{ml}$ MRS medium for $120 \mathrm{~h}$ at $37^{\circ} \mathrm{C}$. The sample treatment method for HPLC was as follows: The fermentation broth was centrifuged at $9000 \mathrm{x} \mathrm{g}$ for $10 \mathrm{~min} ; 1 \mathrm{ml}$ of supernatant was mixed with $9 \mathrm{ml}$ acetonitrile:ultrapure water $(75: 25, \mathrm{v} / \mathrm{v})$; and the intermixture was filtered through an organic phase filter of $0.45 \mu \mathrm{m}$ (Frisenette ApS Co., Ebeltoft, Denmark) and loaded into a $1.5 \mathrm{ml}$ screw-thread bottle $(16,17)$. In the present study, the removal rate of 3MI (\%) was the response value, which was calculated using the following equation: Removal rate $(\%)=(\mathrm{A}-\mathrm{B}) / \mathrm{Ax} 100$; where $\mathrm{A}$ is the initial level of $3 \mathrm{MI}(\mathrm{ng} /$ $\mathrm{ml})$ and $\mathrm{B}$ represents the residual level of $3 \mathrm{MI}(\mathrm{ng} / \mathrm{ml})$.

Removal of 3 MI by the supernatant fluid of fermentation, cell pellets and extracts of lactic acid bacteria. An activated culture of lactic acid bacteria $(10 \mathrm{ml})$ was centrifuged $(9,000 \mathrm{x} \mathrm{g}, 5 \mathrm{~min}$, $5^{\circ} \mathrm{C}$ ). The supernatant fluid of fermentation was collected, and the resultant cell pellets were washed twice with $10 \mathrm{ml}$ sterile PBS (0.01 M, pH 7.4) and suspended in $10 \mathrm{ml}$ sterile PBS. The cell pellet suspension $(10 \mathrm{ml})$ was disintegrated $(400 \mathrm{~W}$ every $5 \mathrm{sec}$ for $30 \mathrm{~min}$ ) in an ice-water bath by an ultrasonic cell disintegrator (Branson Sonifier 450; Branson Ultrasonics Corp., Danbury, CT, USA). The disintegrated cell suspension was centrifuged $\left(9,000 \times \mathrm{g}, 5 \mathrm{~min}, 5^{\circ} \mathrm{C}\right)$ and the supernatant (cell extract) was collected. 3MI was added to the solutions of supernatant fluid of fermentation, suspensions of cell pellets and cell extracts of lactic acid bacteria, to an initial 3MI concentration of $1.0 \mu \mathrm{g} / \mathrm{ml}$. Sterile PBS containing $1.0 \mu \mathrm{g} / \mathrm{ml}$ $3 \mathrm{MI}$ was used as the control. The suspensions were incubated at $37^{\circ} \mathrm{C}$ for $24 \mathrm{~h}$, centrifuged $\left(9,000 \times \mathrm{g}, 5 \mathrm{~min}, 5^{\circ} \mathrm{C}\right)$ and the supernatant fluids were filtered through a $0.45-\mu \mathrm{m}$ filter and stored at $4^{\circ} \mathrm{C}$ prior to analysis $(18,19)$.

Removal of 3MI from PBS by viable heat-, acid-and alkali-treated cells and the supernatant fluid of lactic acid bacteria. Activated culture of L. brevis $1.12(10 \mathrm{ml})$ was centrifuged $\left(9,000 \times \mathrm{g}, 5 \mathrm{~min}, 5^{\circ} \mathrm{C}\right)$ and the cell pellets were washed twice with $10 \mathrm{ml}$ sterile PBS (0.01 M, pH 7.4). Cells of L. brevis 1.12 were treated by the following methods: heating $\left(100^{\circ} \mathrm{C}\right.$ for $30 \mathrm{~min}$, incubated at $37^{\circ} \mathrm{C}$ for $\left.24 \mathrm{~h}\right)$, acid treatment $\left(1 \mathrm{M} \mathrm{HCl}\right.$, incubated at $37^{\circ} \mathrm{C}$ for $24 \mathrm{~h}$ ) and alkali treatment $\left(1 \mathrm{M} \mathrm{NaOH}\right.$, incubated at $37^{\circ} \mathrm{C}$ for $\left.24 \mathrm{~h}\right)$. Following these treatments, the suspensions were centrifuged $\left(9,000 \mathrm{xg}, 5 \mathrm{~min}, 5^{\circ} \mathrm{C}\right)$ and the supernatants were removed. The resultant cell pellets were washed twice with $10 \mathrm{ml}$ sterile PBS and then suspended in $10 \mathrm{ml}$ sterile PBS. Sterile PBS containing $1.0 \mu \mathrm{g} / \mathrm{ml}$ 3MI was used as the control. The removal of $3 \mathrm{MI}$ was tested as previously described. The supernatant fluid of fermentation was cryodesiccated and treated by the same method used for cells of L. brevis $1.12(20,21)$.

Analysis of 3MI by HPLC. For HPLC, an LC-20A system (Shimadzu Co., Kyoto, Japan) was used consisting of a SIL-10ADvp injector with a $100 \mu \mathrm{l}$ loop and two LC-10 ADvp HPLC pumps. The detector used was a RF-20A fluorometer and data were collected with an LC solution integrator. The column was Hypersil (ODS-2, 5- $\mu \mathrm{m}$ particle size; length, $200 \mathrm{~mm}$; tubing I.D, $4.6 \mathrm{~mm}$; Elite Analytical Instrument Co., Ltd., Dalian, China) and operated at ambient temperature. The mobile phase consisted of acetonitrile:ultrapure water (60:40, $\mathrm{v} / \mathrm{v}$ ) and the flow rate was $1.0 \mathrm{ml} / \mathrm{min}$. The detection was carried out by measuring the fluorescence with the following wavelengths: excitation at $281 \mathrm{~nm}$ and emission at $353 \mathrm{~nm}$. The volume of the injected sample was $10 \mu l$ (22).

Statistical analysis. All data are expressed as the mean \pm standard deviation of triplicate assays. Simple linear regressions for 3MI standard solutions with different gradient concentrations and the growth of lactic acid bacteria in the MRS medium with 3MI were calculated using Microsoft Excel 2007. Statistical analyses for the removal rate of 3MI (\%) were carried out using PASW statistics (formerly SPSS), version 18.0 (IBM SPSS, Inc., Chicago, IL, USA).

\section{Results}

Effects of $3 \mathrm{MI}$ on the growth of lactic acid bacteria. The growth responses of lactic acid bacteria (L. brevis 1.12 , L. plantarum 102, L. casei 6103 and L. plantarum ATCC8014) to different concentrations of 3MI (from 0.2 to $1.0 \mu \mathrm{g} / \mathrm{ml}$ ) are shown in Fig. 1.

The effects of 3MI on the growth of L. brevis 1.12 were not significant during the lag phase. However, the growth of L. brevis 1.12 was inhibited by 3 MI during the logarithmic phase. During the stationary phase, the OD values of L. brevis 1.12 in the MRS medium containing 3MI were lower than such values 
of L. brevis 1.12 in MRS medium without 3MI. However, the growth of L. brevis 1.12 was steady as the level of $3 \mathrm{MI}$ increased from 0.2 to $1.0 \mu \mathrm{g} / \mathrm{ml}$ in the stationary phase.

The effects of 3MI on the growth of L.plantarum 102 were not significant at the lag and logarithmic phases. In addition, the results showed that the growth of L. plantarum 102 was not inhibited by $3 \mathrm{MI}$ at the two phases. During the stationary phase, the growth of $L$. plantarum 102 was restrained in the presence of increasing levels of 3MI (from 0.2 to $1.0 \mu \mathrm{g} / \mathrm{ml}$ ) and significant differences between the effects of the various levels of $3 \mathrm{MI}$ on the growth of L. plantarum 102 were observed.

The effects of 3MI on the growth of L. casei 6103 were not significant at the lag and logarithmic phases; however, growth was slower than that of the control group at 10-12 h in the logarithmic phase. At the stationary phase, the growth of L c case $i$ 6103 was restrained in the MRS medium with $0.2 \mu \mathrm{g} / \mathrm{ml} \mathrm{3MI}$, but the OD value was steady as the level of $3 \mathrm{MI}$ increased from 0.2 to $1.0 \mu \mathrm{g} / \mathrm{ml}$. The results suggest that the growth of L. casei 6103 was inhibited by $3 \mathrm{MI}$ at the stationary phase; however, the difference in growth among the varied levels of 3MI was not marked.

The effects of $3 \mathrm{MI}$ on the growth of L. plantarum ATCC8014 were significant at the logarithmic phase, with slower growth compared with that of the control. However, during the stationary phase, the growth was steady with increasing concentrations of $3 \mathrm{MI}$ from 0.2 to $1.0 \mu \mathrm{g} / \mathrm{ml}$.

3MI removal during the fermentation of lactic acid bacteria. The relationship between the concentration of $3 \mathrm{MI}$ and the removal ability of the four strains during the fermentation process was also studied. The results indicate that the levels of $3 \mathrm{MI}$ decreased during the fermentation process in all four strains and the removal rate increased as the incubation time increased from 24 to $120 \mathrm{~h}$. Differences among the four strains were significant, as shown in Table I. L. brevis 1.12 indicated the strongest ability to remove 3MI compared with the other strains. The removal rate increased as the incubation time was extended from 24 to $120 \mathrm{~h}$; however, the effects of different $3 \mathrm{MI}$ levels on the ability of $L$. brevis 1.12 to remove MI were not significant, as the removal rate was steady with increasing levels of $3 \mathrm{MI}$ from 0.2 to $1.0 \mu \mathrm{g} / \mathrm{ml}$; the highest removal rate was $65.35 \pm 0.3 \%$ in the fermentation fluid of $L$. brevis 1.12 with $1.0 \mu \mathrm{g} / \mathrm{ml} \mathrm{3MI}$ in 120 h. For L. plantarum 102, L. casei 6103 and L.plantarum ATCC8014, the effects of the different levels of $3 \mathrm{MI}$ on the removal ability of the three strains were significant. The ability of the three strains to remove $3 \mathrm{MI}$ decreased as the $3 \mathrm{MI}$ levels increased from 0.2 to $1.0 \mu \mathrm{g} / \mathrm{ml}$, and L. plantarum 102 and L. plantarum ATCC8014 were more sensitive to $3 \mathrm{MI}$ when compared with $L$.casei 6103 . The removal ability of L. plantarum 102 and L. plantarum ATCC8014 was sensitive to 0.4 and $0.8 \mu \mathrm{g} / \mathrm{ml} 3 \mathrm{MI}$, respectively. The removal rates were $28.54 \pm 0.2$ and $33.23 \pm 0.9 \%$ in the fermentation fluid of $L$. plantarum 102 and L. plantarum ATCC8014 with $1.0 \mu \mathrm{g} / \mathrm{ml}$ $3 \mathrm{MI}$, respectively, in $120 \mathrm{~h}$.

Mode of removal. The concentrations of 3MI following incubation with the supernatant fluid of fermentation, the suspension of cell pellets and cell extracts of L. brevis 1.12 at $37^{\circ} \mathrm{C}$ for $24 \mathrm{~h}$ were detected by HPLC. The results showed that the $3 \mathrm{MI}$ removal ability of the supernatant fluid of fermentation
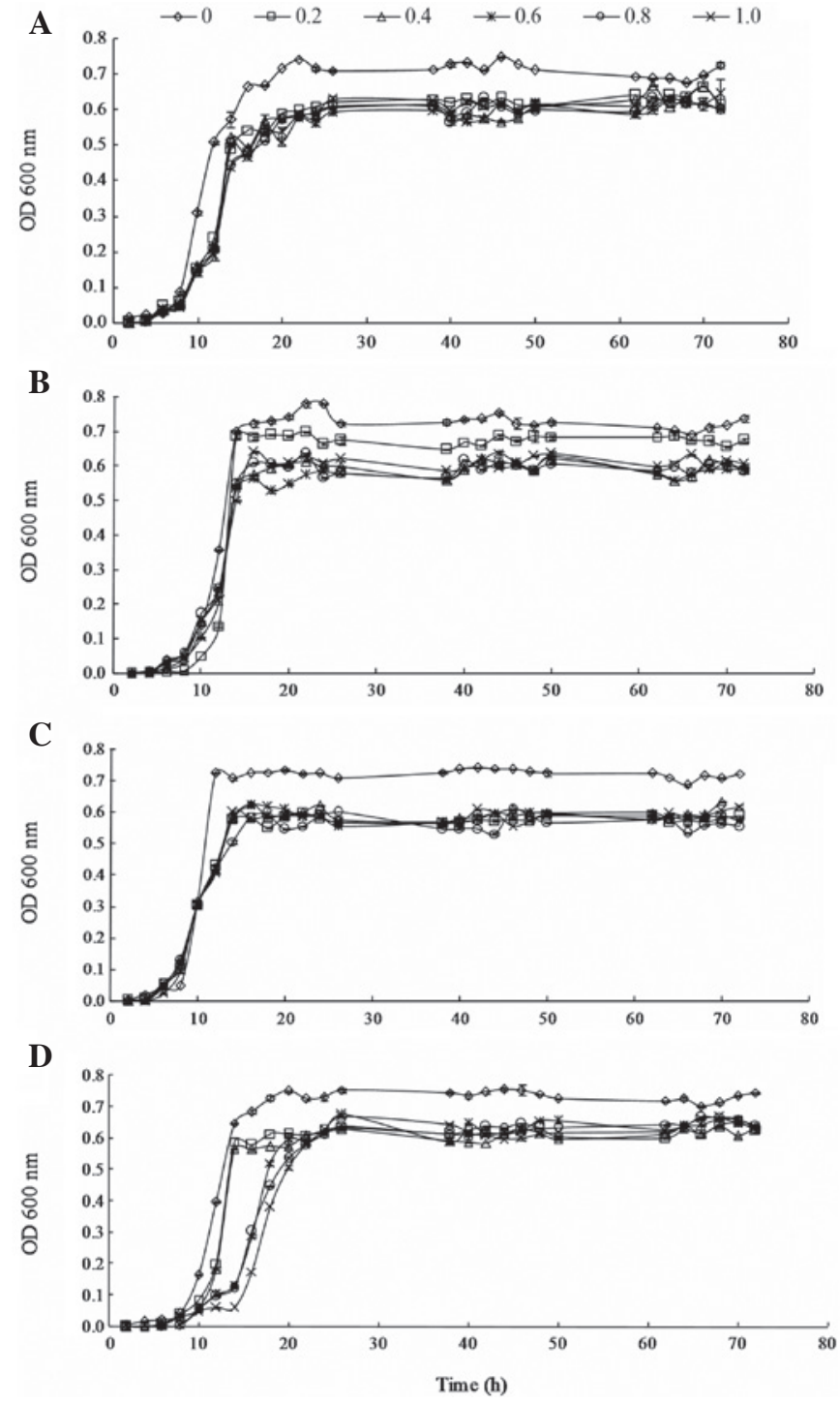

Figure 1. Growth of lactic acid bacteria in MRS medium with $0.2-1.0 \mu \mathrm{g} / \mathrm{ml}$ $3 \mathrm{MI}$ during $72 \mathrm{~h}$ of incubation at $37^{\circ} \mathrm{C}$. Lactic acid bacteria in the MRS broth without $3 \mathrm{MI}$ was used as the control. Different symbols represent the various $3 \mathrm{MI}$ levels. The growth of (A) Lactobacillus brevis 1.12, (B) L. plantarum 102, (C) L. casei 6103 and (D) L. plantarum ATCC8014. 3MI, 3-methylindole; OD, optical density.

broth was the strongest. 3MI was removed by the supernatant fluid of fermentation with a removal rate of $14.4 \pm 0.3 \%$ at $37^{\circ} \mathrm{C}$ for $24 \mathrm{~h}$. 3MI was removed by cell pellets of L. brevis 1.12 $(0.88 \pm 0.2 \%)$ (Fig. 2 ), but $3 \mathrm{MI}$ was not detected in the PBS eluent. The results suggest that the removal mode of $3 \mathrm{MI}$ was not through the physical binding of cells by L. brevis 1.12 . Furthermore, the results showed that the removal rates of 3MI in the suspensions following incubation with heat-, acid- and alkali-treated cells decreased significantly, and the removal ability of L. brevis 1.12 was inhibited under these methods (Table II). The results also confirmed that the removal mode for $3 \mathrm{MI}$ was not via physical binding.

\section{Discussion}

In the present study, the results suggest that the four strains of lactic acid bacteria are more sensitive to $3 \mathrm{MI}$ than previously 
Table I. Effects of the level of 3MI on the 3MI removal ability of lactic acid bacteria.

\begin{tabular}{|c|c|c|c|c|c|}
\hline \multirow{2}{*}{$\begin{array}{l}\text { Concentration } \\
\text { of } 3 \mathrm{MI} \\
(\mu \mathrm{g} / \mathrm{ml})\end{array}$} & \multirow[b]{2}{*}{$\begin{array}{l}\text { Incubation } \\
\text { time }(\mathrm{h})\end{array}$} & \multicolumn{4}{|c|}{ Removal rate (\%) } \\
\hline & & $\begin{array}{c}\text { L. brevis } \\
1.12\end{array}$ & $\begin{array}{c}\text { L. plantarum } \\
102\end{array}$ & $\begin{array}{l}\text { L. casei } \\
6103\end{array}$ & $\begin{array}{c}\text { L. plantarum } \\
\text { ATCC } 8014\end{array}$ \\
\hline \multirow[t]{5}{*}{0.2} & 24 & $15.71 \pm 0.20^{\mathrm{a}}$ & $11.47 \pm 0.40^{\mathrm{b}}$ & $9.20 \pm 0.10^{c}$ & $11.55 \pm 0.20^{b}$ \\
\hline & 48 & $30.62 \pm 0.10^{\mathrm{b}}$ & $39.77 \pm 0.10^{\mathrm{a}}$ & $21.39 \pm 0.40^{\mathrm{c}}$ & $30.50 \pm 0.10^{b}$ \\
\hline & 72 & $57.36 \pm 0.60^{\mathrm{a}}$ & $53.33 \pm 0.30^{\mathrm{c}}$ & $54.23 \pm 1.50^{\mathrm{b}}$ & $50.27 \pm 0.30^{\mathrm{d}}$ \\
\hline & 96 & $62.64 \pm 0.10^{\mathrm{a}}$ & $57.28 \pm 0.10^{c}$ & $60.30 \pm 0.20^{\mathrm{b}}$ & $52.09 \pm 0.10^{\mathrm{d}}$ \\
\hline & 120 & $67.63 \pm 0.20^{\mathrm{a}}$ & $60.79 \pm 0.10^{c}$ & $61.53 \pm 1.20^{\mathrm{b}}$ & $56.75 \pm 0.10^{\mathrm{d}}$ \\
\hline \multirow[t]{5}{*}{0.4} & 24 & $15.36 \pm 0.10^{\mathrm{a}}$ & $9.46 \pm 0.30^{\mathrm{b}}$ & $6.28 \pm 0.60^{c}$ & $9.50 \pm 0.20^{\mathrm{b}}$ \\
\hline & 48 & $29.81 \pm 0.10^{\mathrm{a}}$ & $25.38 \pm 0.10^{\mathrm{b}}$ & $20.72 \pm 0.50^{\mathrm{c}}$ & $17.90 \pm 0.20^{\mathrm{d}}$ \\
\hline & 72 & $57.20 \pm 0.10^{\mathrm{a}}$ & $46.21 \pm 0.50^{c}$ & $53.55 \pm 0.40^{\mathrm{b}}$ & $26.64 \pm 0.90^{\mathrm{d}}$ \\
\hline & 96 & $62.12 \pm 0.10^{\mathrm{a}}$ & $53.51 \pm 0.50^{c}$ & $57.14 \pm 0.20^{\mathrm{b}}$ & $27.32 \pm 0.20^{\mathrm{d}}$ \\
\hline & 120 & $67.87 \pm 0.20^{\mathrm{a}}$ & $55.02 \pm 0.70^{c}$ & $59.16 \pm 0.10^{\mathrm{b}}$ & $35.41 \pm 0.30^{\mathrm{d}}$ \\
\hline \multirow[t]{5}{*}{0.6} & 24 & $15.13 \pm 0.60^{\mathrm{a}}$ & $2.65 \pm 0.40^{\mathrm{d}}$ & $6.21 \pm 0.50^{c}$ & $7.70 \pm 0.80^{b}$ \\
\hline & 48 & $30.93 \pm 0.20^{\mathrm{a}}$ & $19.38 \pm 0.30^{c}$ & $20.16 \pm 0.50^{\mathrm{b}}$ & $17.93 \pm 0.10^{\mathrm{d}}$ \\
\hline & 72 & $57.52 \pm 0.20^{\mathrm{a}}$ & $40.23 \pm 0.60^{c}$ & $46.89 \pm 0.60^{\mathrm{b}}$ & $23.96 \pm 0.10^{\mathrm{d}}$ \\
\hline & 96 & $61.76 \pm 0.40^{\mathrm{a}}$ & $46.72 \pm 0.10^{c}$ & $50.32 \pm 0.60^{\mathrm{b}}$ & $26.73 \pm 0.70^{\mathrm{d}}$ \\
\hline & 120 & $67.61 \pm 0.30^{\mathrm{a}}$ & $47.51 \pm 0.20^{c}$ & $59.14 \pm 0.20^{\mathrm{b}}$ & $35.20 \pm 0.20^{\mathrm{d}}$ \\
\hline \multirow[t]{5}{*}{0.8} & 24 & $16.09 \pm 0.10^{\mathrm{a}}$ & $1.05 \pm 0.10^{\mathrm{d}}$ & $4.21 \pm 0.50^{c}$ & $8.12 \pm 0.30^{\mathrm{b}}$ \\
\hline & 48 & $31.23 \pm 0.20^{\mathrm{a}}$ & $12.44 \pm 0.50^{\mathrm{d}}$ & $17.21 \pm 0.80^{\mathrm{b}}$ & $15.53 \pm 0.40^{\mathrm{c}}$ \\
\hline & 72 & $57.66 \pm 0.20^{\mathrm{a}}$ & $33.35 \pm 0.30^{c}$ & $46.40 \pm 0.40^{\mathrm{b}}$ & $22.35 \pm 0.10^{\mathrm{d}}$ \\
\hline & 96 & $61.63 \pm 0.10^{\mathrm{a}}$ & $35.64 \pm 0.20^{c}$ & $52.18 \pm 0.60^{\mathrm{b}}$ & $23.27 \pm 0.60^{\mathrm{d}}$ \\
\hline & 120 & $67.12 \pm 0.10^{\mathrm{a}}$ & $35.68 \pm 0.30^{\mathrm{c}}$ & $52.76 \pm 0.10^{\mathrm{b}}$ & $35.71 \pm 0.10^{c}$ \\
\hline \multirow[t]{5}{*}{1.0} & 24 & $17.43 \pm 0.20^{\mathrm{a}}$ & $0.88 \pm 0.10^{\mathrm{d}}$ & $3.48 \pm 0.26^{\mathrm{c}}$ & $5.50 \pm 0.40^{\mathrm{b}}$ \\
\hline & 48 & $31.68 \pm 0.20^{\mathrm{a}}$ & $10.62 \pm 0.20^{\mathrm{d}}$ & $16.43 \pm 0.20^{\mathrm{b}}$ & $19.05 \pm 0.90^{\mathrm{c}}$ \\
\hline & 72 & $56.72 \pm 0.60^{\mathrm{a}}$ & $29.60 \pm 0.20^{c}$ & $39.32 \pm 0.30^{\mathrm{b}}$ & $25.42 \pm 0.50^{\mathrm{d}}$ \\
\hline & 96 & $61.55 \pm 0.60^{\mathrm{a}}$ & $29.63 \pm 0.10^{c}$ & $51.78 \pm 0.20^{\mathrm{b}}$ & $26.16 \pm 0.50^{\mathrm{d}}$ \\
\hline & 120 & $65.35 \pm 0.30^{\mathrm{a}}$ & $28.54 \pm 0.20^{\mathrm{d}}$ & $52.15 \pm 0.30^{\mathrm{b}}$ & $33.23 \pm 0.90^{\mathrm{c}}$ \\
\hline
\end{tabular}

Values are the mean \pm standard deviation of triplicate assays. Values in a row with the same letter are not significantly different $(\mathrm{P}>0.05)$ and values in a row with different letters are significantly different $(\mathrm{P}<0.05)$. 3MI, 3-methylindole; L., Lactobacillus.

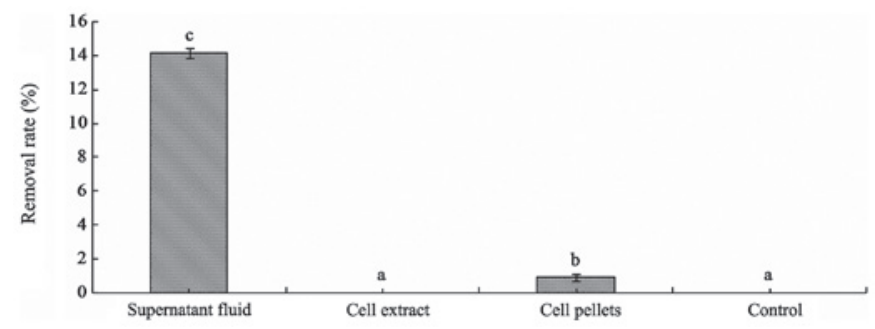

Figure 2. Removal rate of 3MI following incubation with the supernatant fluid of fermentation, suspension of cell pellets and cell extracts of $L$. brevis 1.12 at $37^{\circ} \mathrm{C}$ for $24 \mathrm{~h}$. Sterile PBS containing $1.0 \mu \mathrm{g} / \mathrm{ml} 3 \mathrm{MI}$ was used as the control. Values of columns labeled with different letters were significantly different $(\mathrm{P}<0.05)$. 3MI, 3-methylindole; PBS, phosphate-buffered saline.

investigated microorganisms from other studies regarding the effects of $3 \mathrm{MI}$ on microorganisms. The growth of all four strains was inhibited by low levels of 3MI $(0.2 \mu \mathrm{g} / \mathrm{ml})$. However, Dreizen and Spies (23) identified that the growth of $L$. acidophilus was completely restricted by $400 \mu \mathrm{g} / \mathrm{ml}$
3MI, but growth occurred when the 3MI concentration was decreased from 400 to $100 \mu \mathrm{g} / \mathrm{ml}$. In addition, Tittlser et al (24) demonstrated that the growth of 25 species of Gram-negative bacteria extracted from the intestinal tract was inhibited when the $3 \mathrm{MI}$ concentration was $330 \mu \mathrm{g} / \mathrm{ml}$. Furthermore, Kohda et al (12) identified that the growth of Clostridium was steady in 100-300 $\mu \mathrm{g} / \mathrm{ml}$ 3MI solution; however, the growth of certain clostridia was prevented in $50 \mu \mathrm{g} / \mathrm{ml} 3 \mathrm{MI}$ solution. In the present study, the growth of the four strains was prevented in the incubation environment with $0.2 \mu \mathrm{g} / \mathrm{ml} 3 \mathrm{MI}$ and the tolerance levels for $3 \mathrm{MI}$ concentration were lower than those identified in the previously mentioned studies.

Furthermore, the ability of the four strains to degrade 3MI was compared with results from previous studies. The results showed that the $3 \mathrm{MI}$ removal ability of the four strains was stronger than that of the microorganisms investigated in the studies by Gu et al (15) and Li et al (25). Gu et al (15) identified that $3 \mathrm{MI}$ may be degraded by marine anaerobic microorganisms for 30 days. Additionally, Li et al (22) indicated that $2.0 \mathrm{mmol} / 13 \mathrm{MI}$ may be degraded by Pseudomonas putida LPC 24 in $<30$ days. 
Table II. Effects of supernatant and cell pellets of L. brevis 1.12 on 3MI removal using different treatment methods.

Removal rate $(\%)$

\begin{tabular}{lcccccc}
\cline { 2 - 6 } Substance & Heat-treated & Acid-treated & Alkali-treated & Non-treated & HCl control & NaOH control \\
\hline Supernatant & $3.98 \pm 1.3^{\mathrm{a}}$ & $6.70 \pm 0.7^{\mathrm{c}}$ & $4.92 \pm 1.2^{\mathrm{b}}$ & $15.27 \pm 2.3^{\mathrm{d}}$ & - & - \\
Cell pellets & - & - & - & $0.95 \pm 1.5$ & - & - \\
\hline
\end{tabular}

Incubation time was $24 \mathrm{~h}$ at $37^{\circ} \mathrm{C}$. Values are the mean \pm standard deviation of triplicate assays. Values in a row with different letters are significantly different. L., Lactobacillus.

In the present study, the degradation ability of L. brevis 1.12 was the strongest among the bacteria tested, with a degradation rate for $1.0 \mu \mathrm{g} / \mathrm{ml} 3 \mathrm{MI}$ of $65.35 \pm 0.3 \%$ in 5 days. However, the degradation time was longer than that in the study by Yin et al (13). The study suggested that $2.5 \mathrm{mmol} / 13 \mathrm{MI}$ may be reduced by Pseudomonas aeruginosa (extracted from the sediment of lapacho wood) in 3 days and the time extended with increased 3MI concentration from 2.5 to $3.5 \mathrm{mmol} / \mathrm{l}(13)$. The different results may be due to significant differences among the microorganisms tested.

The results of the present study demonstrated that $3 \mathrm{MI}$ may be degraded by the supernatant fluid of fermentation and suspension of cell pellets; however, 3MI was not detected in the eluent of cell pellets. This suggests the key substance responsible for the degradation of 3MI exists in the supernatant fluid of the fermentation broth and that the mode of $3 \mathrm{MI}$ removal was not through the physical binding of cells by L. brevis 1.12 . However, in the present study, the removal mechanism of $3 \mathrm{MI}$ during the fermentation process of L. brevis 1.12 was not studied. The removal mechanism of $3 \mathrm{MI}$ in certain microorganisms and the liver of entire pigs have been demonstrated in previous studies. Gu et al (15) identified that 3MI may be degraded by marine anaerobic microorganisms, and the mechanism included two steps of oxidation accomplished by hydroxylation and then dehydrogenation at the 2- and 3-positions sequentially prior to the cleavage of the pyrrole ring between the 2- and 3 -positions. The 3MI degradation mechanism in pig liver is usually conducted in two steps, phase I and II (26). Phase I consists of an oxidation of the compound, usually catalyzed by cytochrome P450 (CYP450) enzymes, while phase II is conducted by a more diverse group of enzymes and consists of conjugation with a hydrophilic group, such as by glucuronidation, sulfoconjugation or glucosidation. The outcome of phase I and/or II metabolism is often the elimination of the compound by excretion (26). In pigs, the phase I metabolism of 3MI is mainly mediated by hepatic CYP1A2, CYP2A and CYP2E1 (27). Diaz and Squires (28) indicated that 3MI is metabolized by the CYP450 system in the lungs and liver of ruminants, rodents and humans. Squires and Lundström (26) demonstrated that a similar system may be involved in $3 \mathrm{MI}$ metabolism in pigs and a particular CYP2E1 was indicated as the major enzyme responsible for metabolic breakdown of $3 \mathrm{MI}$ in the liver. Moreover, Chen et al (8) identified that a dietary supplement of raw potato starch reduced the levels of 3MI. Furthermore, the addition of fructooligosaccharide to pig fecal slurries significantly reduced $3 \mathrm{MI}$ levels but not indole synthesis from tryptophan. In future studies, the supernatant fluid of the fermentation broth with 3MI will be detected using HPLC to analyze whether new metabolites are produced and to study the mechanism of 3MI degradation by L. brevis 1.12 .

In conclusion, the present study used various in vitro experimental methods to investigate the growth of lactic acid bacteria in the presence of $3 \mathrm{MI}$, the $3 \mathrm{MI}$ removal ability of four strains of bacteria during the fermentation process and the removal mode of $3 \mathrm{MI}$ by L. brevis 1.12 . The results demonstrated that the growth of all four strains was inhibited by $3 \mathrm{MI}$ and the $3 \mathrm{MI}$ removal ability of $L$. brevis 1.12 was the strongest. The 3MI removal rate of $L$. brevis 1.12 was $65.35 \pm 0.3 \%$ from the incubation medium of $1 \mathrm{ml} 1.0 \mu \mathrm{g} / \mathrm{ml} 3 \mathrm{MI}$ in $120 \mathrm{~h}$. Furthermore, this study demonstrated that the mode of $3 \mathrm{MI}$ removal was not through the physical binding of cells by L. brevis 1.12 .

\section{Acknowledgements}

This study was funded by the National Basic Research Program of China (973 program; grant no. 2009CB118806), the National Rabbit Industry Technology System Program (grant no. CARS-44D-1) and the National Natural Science Foundation of China (grant no. 31071566).

\section{References}

1. Barton Gade PA: Meat and fat quality in boars, castrates and gilts. Livest Prod Sci 16: 187-196, 1987.

2. Bonneau M, Dufour R, Chouvet C, Roulet C, Meadus W and Squires EJ: The effects of immunization against luteinizing hormone-releasing hormone on performance, sexual development, and levels of boar taint-related compounds in intact male pigs. J Anim Sci 72: 14-20, 1994.

3. Babol J, Squires EJ and Lundström K: Relationship between metabolism of androstenone and skatole in intact male pigs. J Anim Sci 77: 84-92, 1999.

4. Babol J, Squires EJ and Lundström K: Hepatic metabolism of skatole in pigs by cytochrome P4502E1. J Anim Sci 76: 822-828, 1998.

5. Jensen MT, Cox RP and Jensen BB: 3-Methylindole (skatole) and indole production by mixed populations of pig fecal bacteria. Appl Environ Microbiol 61: 3180-3184, 1995.

6. Yokoyama MT and Carlson JR: Microbial metabolites of tryptophan in the intestinal tract with special reference to skatole. Am J Clin Nutr 32: 173-178, 1979.

7. Lunde K, Skuterud E, Hersleth M and Egelandsdal B: Norwegian consumers' acceptability of boar tainted meat with different levels of androstenone or skatole as related to their androstenone sensitivity. Meat Sci 86: 706-711, 2010. 
8. Chen G, Zamaratskaia G, Andersson HK and Lundström K: Effects of raw potato starch and live weight on fat and plasma skatole, indole and androstenone levels measured by different methods in entire male pigs. Food Chem 101: 439-448, 2007.

9. Yuan YJ, Lu ZX, Huang LJ, Li Y, Lu FX, Bie XM, et al: Biodegradation of nicotine from tobacco waste extract by Ochrobactrum intermedium DN2. J Ind Microbiol Biotechnol 34: 567-570, 2007.

10. Bai YH, Sun Q, Zhao C, Wen D and Tang X: Aerobic degradation of pyridine by a new bacterial strain, Shinella zoogloeoides BC026. J Ind Microbiol Biotechnol 36: 1391-1400, 2009.

11. Patil PS, Shedbalkar UU, Kalyani DC and Jadhav JP: Biodegradation of Reactive Blue 59 by isolated bacterial consortium PMB11. J Ind Microbiol Biotechnol 35: 1181-1190, 2008.

12. Kohda C, Ando T and Nakai Y: Isolation and characterization of anaerobic indole- and skatole-degrading bacteria from composting animal wastes. J Gen Appl Microbiol 43: 249-255, 1997.

13. Yin B, Huang L and Gu JD: Biodegradation of 1-methylindole and 3-methylindole by mangrove sediment enrichment cultures and a pure culture of an isolated Pseudomonas aeruginosa Gs. Water Air Soil Poll 176: 185-199, 2006.

14. Gu JD and Berry DF: Metabolism of 3-methylindole by a methanogenic consortium. Appl Environ Microbiol 58: 2667-2669, 1992.

15. Gu JD, Fan Y and Shi H: Relationship between structures of substituted indolic compounds and their removal by marine anaerobic microorganisms. Mar Pollut Bull 45: 379-384, 2002.

16. El-Nezami HS, Polychronaki N, Salminen S and Mykkänen H: Binding rather than metabolism may explain the interaction of two food-grade Lactobacillus strains with zearalenone and its derivative ó-zearalenol. Appl Environ Microbiol 68: 3545-3549, 2002.

17. Niderkorn V, Boudra $\mathrm{H}$ and Morgavi DP: Binding of Fusarium mycotoxins by fermentative bacteria in vitro. J Appl Microbiol 101: 849-856, 2006.
18. Cheng B, Wan C, Yang S, Xu H, Wei H, Liu J, et al: Detoxification of deoxynivalenol by Bacillus strains. J Food Safety 30: 599-614, 2010.

19. Lu Q, Liang X and Chen F: Detoxification of zearalenone by viable and inactivated cells of Planococcus sp. Food Control 22: 191-195, 2011.

20. El-Nezami HS, Kankaanpaa PE, Salminen S and Ahokas J: Ability of dairy strains of lactic acid bacteria to bind a common food carcinogen, afatoxin B1. Food Chem Toxicol 36: 321-326, 1998.

21. Topcu A, Bulat T, Wishah R and Boyaci IH: Detoxification of aflatoxin $\mathrm{B} 1$ and patulin by Enterococcus faecium strains. Int $\mathrm{J}$ Food Microbiol 139: 202-205, 2010.

22. Tuomola M, Vahva M and Kallio H: High-performance liquid chromatography determination of skatole and indole levels in pig serum, subcutaneous fat, and submaxillary salivary glands. J Agr Food Chem 44: 1265-1270, 1996.

23. Dreizen S and Spies TD: Further studies on the association between the products of protein putrefaction and dental caries activity. J Dent Res 27: 305-315, 1948.

24. Tittsler RP, Sandholzer LA and Callahan ET: The bacteriostatic action of skatole on Gram-negative enteric bacilli. J Infect Dis 57: 57-60, 1935.

25. Li P, Tong L, Liu K, Wang YX: Biodegradation of 3-methylindole by Pseudomonas putida LPC24 under oxygen limited conditions. Fresenius Environ Bull 19: 238-242, 2010.

26. Squires EJ and Lundström K: Relationship between cytochrome P4502E1 in liver and levels of skatole and its metabolites in intact male pigs. J Anim Sci 75: 2506-2511, 1997.

27. Matal J, Matuskova Z, Tunkova A, Anzenbacherova E and Anzenbacher P: Porcine CYP2A19, CYP2E1 and CYP1A2 forms are responsible for skatole biotransformation in the reconstituted system. Neuro Endocrinol Lett 30: 36-40, 2009.

28. Diaz GJ and Squires EJ: Metabolism of 3-methylindole by porcine liver microsomes: responsible cytochrome P450 enzymes. Toxicol Sci 55: 284-292, 2000. 